\title{
Extracellular Proteins Involved in Soybean Cultivar-Specific Nodulation Are Associated with Pilus-Like Surface Appendages and Exported by a Type III Protein Secretion System in Sinorhizobium fredii USDA257
}

\author{
Hari B. Krishnan, ${ }^{1}$ Julio Lorio, ${ }^{2}$ Won Seok Kim, ${ }^{3}$ Guoqiao Jiang, ${ }^{2}$ Kil Yong Kim, ${ }^{4}$ Margreet DeBoer, ${ }^{2}$ and \\ Steven G. Pueppke ${ }^{2}$ \\ ${ }^{1}$ Plant Genetics Research Unit, United States Department of Agriculture-Agricultural Research Service, University of \\ Missouri, Columbia 65211, U.S.A.; ${ }^{2}$ Department of Plant Microbiology and Pathology, University of Missouri; ${ }^{3}$ Department \\ of Agronomy, University of Missouri; ${ }^{4}$ Department of Agricultural Chemistry, Agricultural Plant Stress Research Center, \\ Chonnam National University, Kwang-Ju, Korea
}

Submitted 7 October 2002. Accepted 26 February 2003.

Several gram-negative plant and animal pathogenic bacteria have evolved a type III secretion system (TTSS) to deliver effector proteins directly into the host cell cytosol. Sinorhizobium fredii USDA257, a symbiont of soybean and many other legumes, secretes proteins called Nops (nodulation outer proteins) into the extracellular environment upon flavonoid induction. Mutation analysis and the nucleotide sequence of a 31.2-kb symbiosis (sym) plasmid DNA region of USDA257 revealed the existence of a TTSS locus in this symbiotic bacterium. This locus includes rhc (rhizobia conserved) genes that encode components of a TTSS and proteins that are secreted into the environment (Nops). The genomic organization of the TTSS locus of USDA257 is remarkably similar to that of another broadhost range symbiont, Rhizobium sp. strain NGR234. Flavonoids that activate the transcription of the nod genes of USDA257 also stimulate the production of novel filamentous appendages known as pili. Electron microscope examination of isolated pili reveals needle-like filaments of 6 to 8 $\mathrm{nm}$ in diameter. The production of the pili is dependent on a functional nodD1 and the presence of a nod gene-inducing compound. Mutations in several of the TTSS genes negate the ability of USDA257 to elaborate pili. Western blot

Corresponding author: H. B. Krishnan; E-mail: KrishnanH@missouri.edu; 108W Curtis Hall, USDA-ARS Department of Agronomy, Columbia; Telephone: 573-882-8151; Fax: 573-884-7850.

Current address for G. Jiang: Biotechnology Laboratory, The University of British Columbia, Vancouver, B.C., Canada.

Current address for S. G. Pueppke: College of Agricultural, Consumer, and Environmental Sciences, University of Illinois, Urbana 60801, U.S.A.

This paper reports the results of research only. Mention of a proprietary product does not constitute an endorsement or a recommendation for its use by the USDA-ARS.

Nucleotide and amino acid sequence data for the USDA257 TTSS locus is available in the GenBank database under accession number AF229441.

This article is in the public domain and not copyrightable. It may be freely reprinted with customary crediting of the source. The American Phytopathological Society, 2003. analysis using antibodies raised against purified NopX, Nop38, and Nop7 reveals that these proteins were associated with the pili. Mutations in $r h c N, r h c J, r h c C$, and ttsI alter the ability of USDA257 to form nodules on Glycine max and Macroptilium atropurpureum.

Many legumes have the ability to establish a symbiotic association with certain soil bacteria of the genera Azorhizobium, Bradyrhizobium, Sinorhizobium, Mesorhizobium, and Rhizobium (collectively identified as rhizobia). This association leads to the formation of specialized organs called nodules. Bacteria within the nodules differentiate into nitrogen-fixing bacteroids, which reduce nitrogen to ammonia for use in plant growth and development. In exchange, the plant provides a specialized environment and carbohydrates to the rhizobia.

The induction of nodules on legume roots requires at least three sets of symbiotic signals to be exchanged between the partners (Broughton et al. 2000). The first signals are flavonoids, plant-derived molecules that interact with NodD and activate the transcription of several key nodulation (nod) genes in the microsymbiont. The products of some of these genes are involved in the synthesis of a second set of signal molecules, Nod-factors, that play a crucial role in developmental initiation of nodules on legume roots. A third group of signal molecules comprising extracellular polysaccharides, lipopolysaccharides, and flavonoid-induced extracellular proteins, also play important but not fully understood roles in infection thread formation, nodulation efficiency, and nitrogen fixation (Krishnan 2002; Leigh et al. 1985; Sutton et al. 1994; Viprey et al. 1998).

Sinorhizobium fredii USDA257 (hereafter called USDA257) forms nodules on soybean in a cultivar-specific manner. Nitrogen-fixing nodules are produced on the soybean cultivar 'Peking' but not on agronomically advanced cultivar 'McCall' (Heron and Pueppke 1984). Random transposon mutagenesis confirmed that a plasmid-borne locus, nolXWBTUV, is involved in regulating soybean cultivar specificity (Meinhardt et al. 1993). Most of the genes located in this locus are induced by flavonoid signals, and their protein products reveal significant sequence homology to components of a type III secretion system (TTSS) (Meinhardt et 
al. 1993). USDA257 secretes several extracellular proteins, designated as signal responsive (SR) proteins, into the rhizosphere upon flavonoid induction (Krishnan and Pueppke 1993). N-terminal amino acid sequence determination of one of the SR proteins indicated export without $\mathrm{N}$-terminal processing, a hallmark of proteins that are secreted by TTSS. Disruption of the nolXWBTUV locus also abolished the secretion of the SR proteins (Krishnan et al. 1995). These observations indicate that SR proteins may be transported through TTSS, and some products of the nolXWBTUV may code for the components of TTSS in USDA257. Proteins secreted by TTSS in Yersinia species are called Yops (Yersinia outer proteins), and Marie and associates (2001) have proposed Nops (nodulation outer proteins) for Rhizobium proteins that are secreted by TTSS. Based on this proposal, previously identified TTSS-dependent secreted proteins, such as NolX and $\mathrm{y} 4 \mathrm{xL}$, have been renamed as NopX and NopL (Marie et al. 2001).

Several plant and animal pathogenic bacteria employ the TTSS to transfer virulence proteins directly into the host cells (Brown et al. 2001; Casper-Lindley et al. 2002; Galan and Collmer 1999; Lee 1997). These systems have been extensively characterized, and some common features of TTSS can be derived. The TTSS, which is genetically and morphologically similar to the bacterial flagellum, is activated by host cell contact in vivo (Pettersson et al. 1996). The secretion signal is localized in the $5^{\prime}$ region of the mRNA or at the amino terminus of the secreted protein, and often the TTSS is associated with filamentous appendages (Anderson and Schneewind 1997; Lloyd et al. 2002). The presence of a macromolecular complex, termed a needle complex, that spans both the inner and outer bacterial membranes with a needle-like projection that projects outward from the bacterial membrane has been described in Salmonella typhimurium (Kubori et al. 1998). These structures are about $120 \mathrm{~nm}$ long and are composed of at least three proteins, InvG, $\operatorname{PrgH}$, and $\operatorname{PrgK}$ (Kubori et al. 1998). In addition to needle complexes, filamentous append- ages, which vary in size from 8 to $50 \mathrm{~nm}$ in diameter, may also be involved in transport of virulence factors into the host cells (Ginocchio et al. 1994; Jin and He 2001; Roine et al. 1997; Van Gijsegem et al. 2000).

Unlike animal and plant bacterial pathogens, very little is known about TTSS in symbiotic rhizobia. Here, we report the genetic organization and sequence of a 31.2-kb DNA region that includes the entire type III protein secretion machinery of USDA257. The TTSS of USDA257 also elaborates filamentous appendages upon induction with soybean root exudates. Biochemical analysis reveals the presence of several Nops in the purified filamentous appendages.

\section{RESULTS}

Type III secretion genes in $S$. fredii USDA257.

Screening an USDA257 genomic library with a ${ }^{32} \mathrm{P}$-labeled 8.0-kb EcoRI fragment known to contain the nolXWBTUV locus resulted in the identification of four positive cosmid clones. Cosmid clone pHBK447, with a total insert size of 28.8 $\mathrm{kb}$, contained 10 EcoRI fragments. The complete nucleotide sequence of one of the EcoRI fragments (pRFDH410) has been reported earlier and contains several open reading frames (ORFs), some of which show strong sequence homology to hrc (hypersensitive response and pathogenesis conserved) genes of plant and pathogenic bacteria (Meinhardt et al. 1993). Two ORFs, ORF4 and nolV, located downstream of nolU, were identified in this region (Meinhardt et al. 1993). These two ORFs show significant homologies to the $\mathrm{N}$ - and C-terminals of nolV from NGR234, S. fredii HH103, B. japonicum USDA110, and M. loti MAFF303099. This led us to resequence this region in USDA257. The earlier published sequence had one base pair deleted, resulting in introduction of a stop codon and truncating the nolV sequences. We have now corrected this error, and the revised version of the sequence (GenBank accession number AF229441) codes for NolV of a comparable size as from other rhizobia.
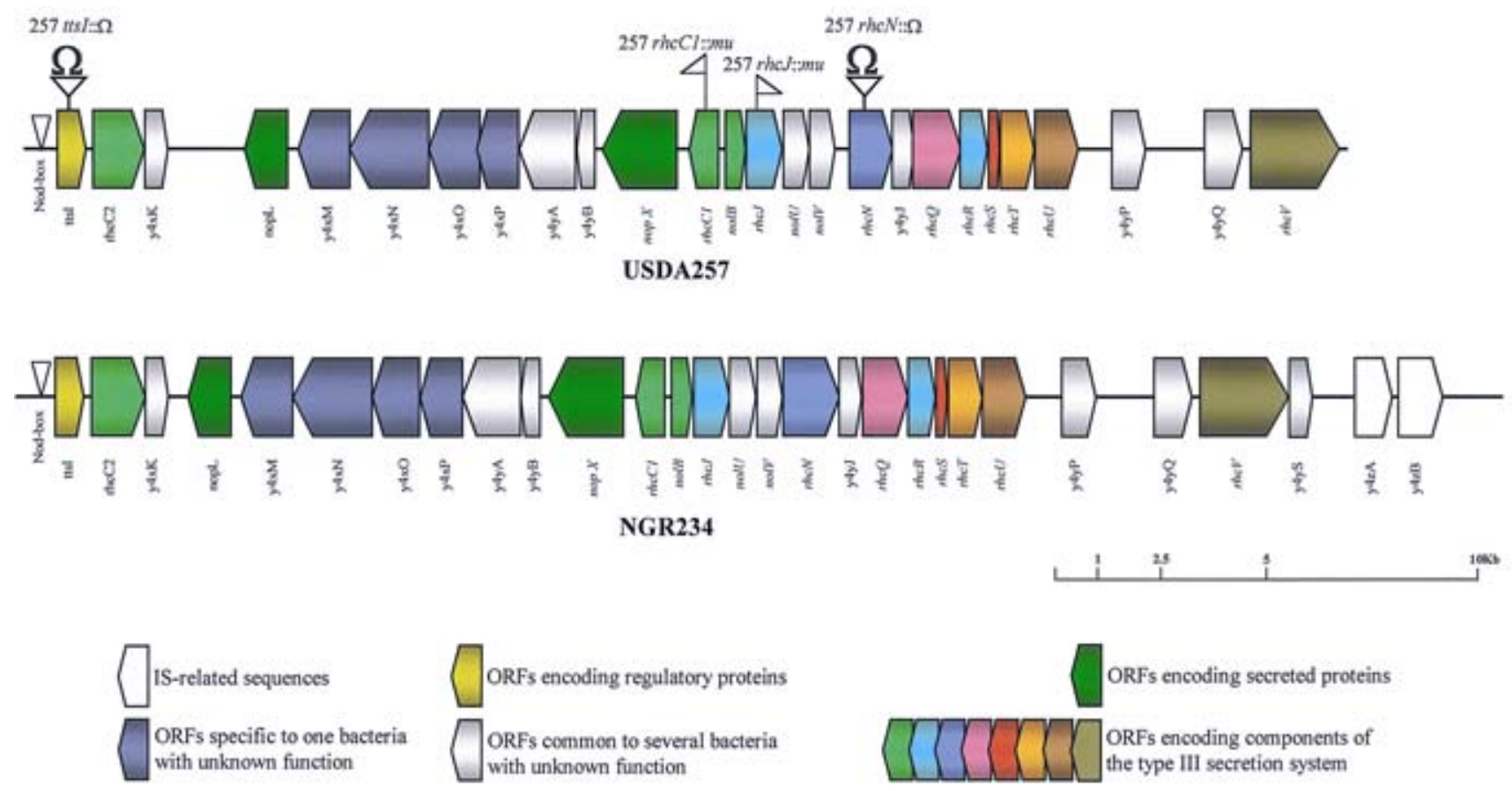

Fig. 1. Genetic organization of the type III secretion system genes of Sinorhizobium fredii USDA257 and Rhizobium sp. strain NGR234. Predicted open reading frames (ORFs) are shown as arrow-shaped boxes, oriented according to their direction of transcription (Marie et al. 2001). The positions of mini$\mathrm{Mu}$ insertion and omega interposon in USDA257 are also shown. Similar coloring represents homologous ORFs. Accession numbers are: USDA257, AF229441 and NGR234, AE000108. 
Recent sequence information has confirmed the presence of a TTSS on the symbiotic plasmid of Rhizobium sp. strain NGR234 (hereafter termed NGR234) (Freiberg et al. 1997) and R. elti CFN42 (NCBI database, accession number U80928) and in the genome of M. loti MAF303099 (Kaneko et al. 2000) and B. japonicum USDA110 (Göttfert et al. 2001). The TTSS in these rhizobia are clustered within regions of 35 to $47 \mathrm{~kb}$ (Marie et al. 2001). These clusters include genes that encode
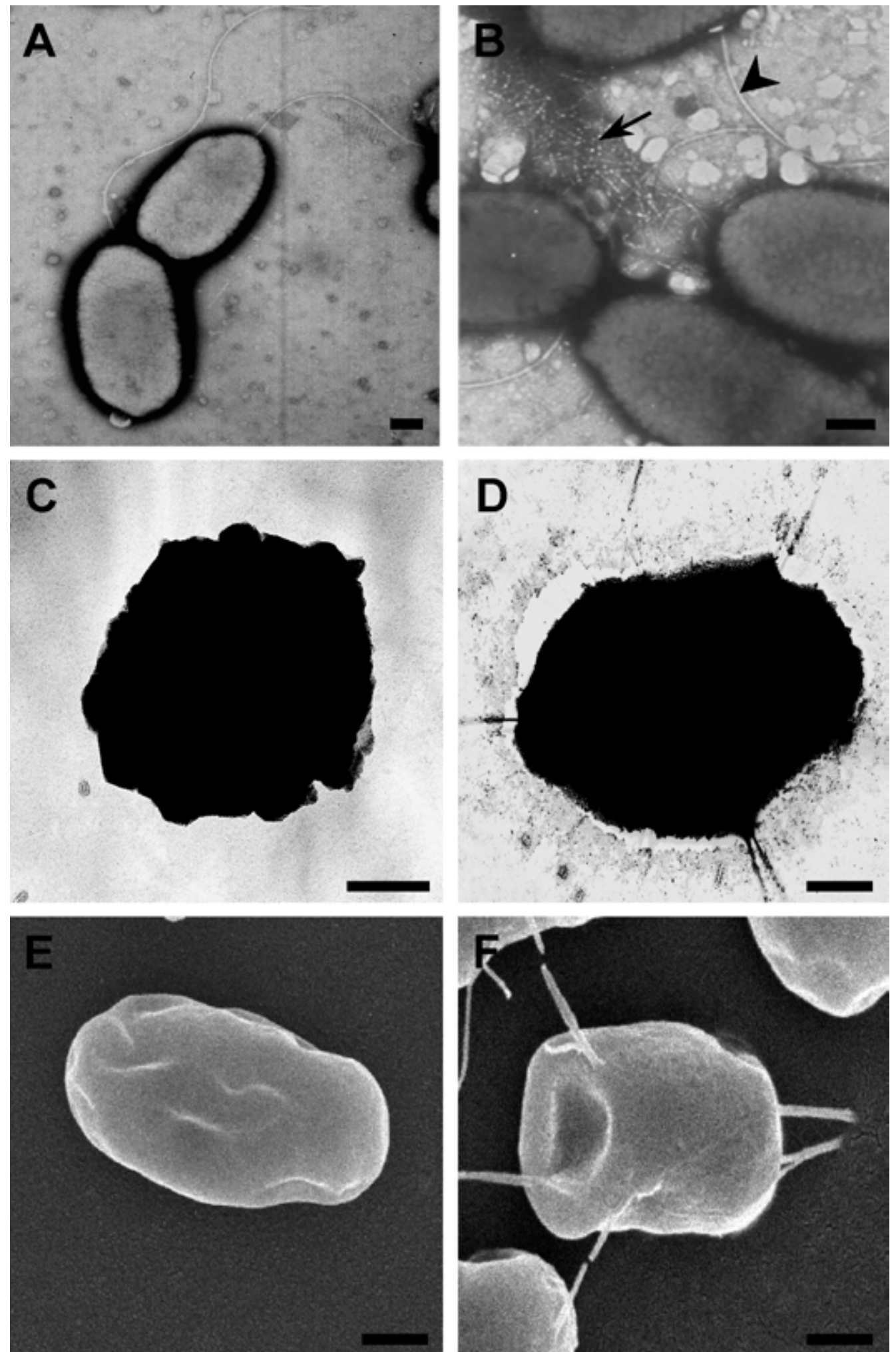

Fig. 2. Electron micrographs of surface appendages produced by USDA257. Cells of Sinorhizobium fredii USDA257 grown in yeast extract-manitol (YEM) agar plates were negatively stained with $1 \%$ phosphotungstic acid ( $\mathrm{pH}$ 6.5). A, Cells grown in the absence of genistein elaborate flagella of 10 to $12 \mathrm{~nm}$ in diameter. B, Addition of genistein results in the production of pilus-like filaments (indicated by arrows) that are thinner than flagella (arrowhead). C and E, USDA257 cells grown in the absence of genistein reveal no surface appendages, while $\mathbf{D}$ and $\mathbf{F}$, cells grown in the presence of genistein produce pili-like appendages. In D and F, chemical fixation of USDA257 cells grown in YEM liquid media improves the visualization of pili (indicated by arrows). Micrographs of negatively stained USDA257 cells are shown in C and D. The micrographs shown in E and F were obtained with a cold field emission scanning electron microscope. Bars $=0.25 \mu \mathrm{m}$ 
the secretion apparatus as well as proteins that are secreted to the rhizosphere. To examine whether a similar physical organization of TTSS also occurs in USDA257, we sequenced all of the remaining nine EcoRI fragments of pHBK447. We extended the sequence by sequencing a 3-kb DNA region from another overlapping cosmid (pRK1489).

The genetic organization of the TTSS of USDA257 is strikingly similar to that of NGR234, a strain that nodulates more than 110 genera of legumes (Pueppke and Broughton 1999). The sequenced region revealed 26 predicted ORFs delineated by y4xI and y4yR (Fig. 1). Nine of the ORFs (y4yD, y4yF, $\mathrm{y} 4 \mathrm{yM}, \mathrm{y} 4 \mathrm{yL}, \mathrm{y} 4 \mathrm{yN}, \mathrm{y} 4 \mathrm{yR}, \mathrm{y} 4 \mathrm{yO}, \mathrm{y} 4 \mathrm{yI}$, and $\mathrm{y} 4 \mathrm{yK})$ showed extensive homology to $h r c$ genes that encode the components of the TTSS apparatus of plant and animal pathogenic bacteria. To distinguish the TTSS components of symbiotic rhizobia from plant pathogenic bacteria, Viprey and associates (1998) proposed to name the 'Hrc' protein homologues as 'Rhc' (rhizobia conserved). To maintain a uniform nomenclature, we have also assigned the Rhc designation for all the components of the TTSS machinery of USDA257 (Fig. 1). Based on the structure of the TTSS apparatus of $P$. syringae (Baker et al.
1997), it is suggested that RhcC1 and RhcC2, which encode the $\mathrm{N}$ - and $\mathrm{C}$-terminal domains of $\mathrm{HrcC}$, code for the outer membrane protein. RhcJ codes for an outer membrane lipoprotein and RhcR, RhcS, RhcT, RhcU, and RhcQ all code for inner membrane proteins. Two cytoplasmic proteins, RhcQ and RhcN, are also part of the TTSS machinery of NGR234 and USDA257 (Fig. 1). A similar gene arrangement is also found in $M$. loti, except that $\mathrm{y} 4 \mathrm{yP}, \mathrm{y} 4 \mathrm{xP}, \mathrm{y} 4 \mathrm{xN}$, and $\mathrm{y} 4 \mathrm{xM}$ are absent in the TTSS of this organism (Marie et al. 2001). In B. japonicum, the $\mathrm{y} 4 \mathrm{x} 1-\mathrm{rhcC} 2-\mathrm{y} 4 \mathrm{xK}$ and $\mathrm{y} 4 \mathrm{yQ}-\mathrm{rhcV}-\mathrm{y} 4 \mathrm{yS}$ cluster is divergently oriented when compared with NGR234, USDA257, and M. loti counterparts (Marie et al. 2001). In addition, the TTSS of B. japonicum USDA110 contains several ORFs that are not present in other symbiotic bacteria (Göttfert et al. 2001). The complete nucleotide sequence of Rhizobium etli CFN42 symbiotic plasmid p42d has been recently elucidated (accession number U80928). Sequence analysis indicates that $R$. etli also contains a TTSS. Some of the components of the TTSS, such as $r h c C$, were not detected in this region. In addition, the organization of the $r h c$ genes was also different when compared with other symbiotic bacteria. In spite of these dif-
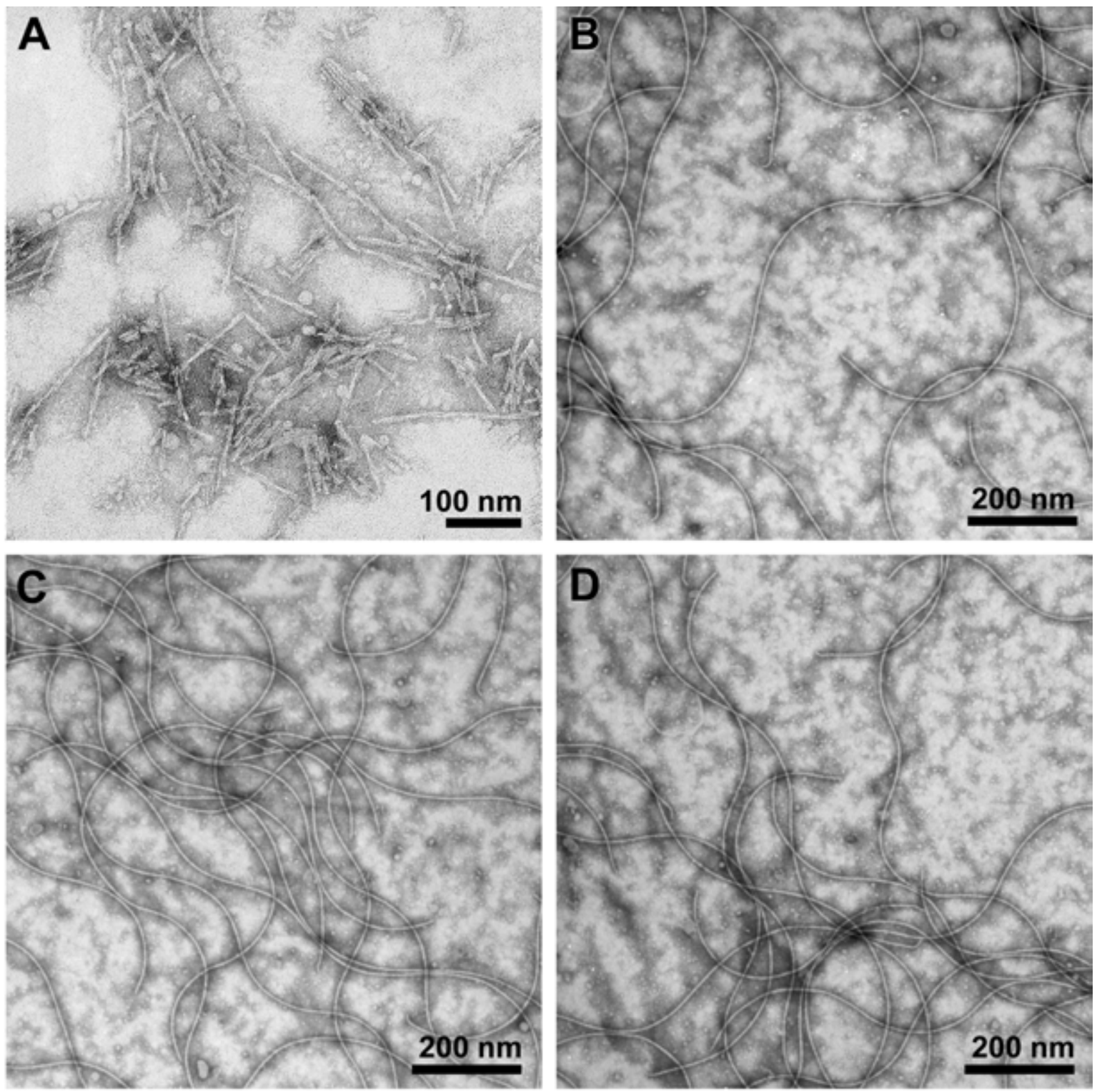

Fig. 3. Electron micrographs of the isolated surface appendages of Sinorhizobium fredii USDA257. A, Surface appendages from USDA257, B, rhcN, C, $t t s I$, and $\mathbf{D}$, nodD mutants grown in yeast extract-mannitol liquid media containing genistein were examined with a transmission electron microscope after staining with $1 \%$ phosphotungstic acid (pH 6.5). Note that $r h c N$, ttsI, and nodD1 mutants do not elaborate pili. 
ferences, the rhc genes appear to be conserved among all the symbiotic bacteria that contain a TTSS.

\section{Flavonoids stimulate USDA257 \\ to produce pilus-like surface appendages.}

Electron-microscope observation of USDA257 cells grown in yeast extract-mannitol (YEM) agar plates revealed the presence of several flagella (Fig. 2A). Isolated flagella filaments have a diameter of approximately 10 to $12 \mathrm{~nm}$. In contrast to the complex flagella of $S$. meliloti (Krupski et al. 1985), the USDA257 flagella filaments are structurally simple. Addition of the isoflavone genistein, a potent inducer of nod genes of USDA257, to the culture media resulted in the production of a second type of appendage. These pilus-like appendages are much thinner than flagella and are elaborated in abundance (Fig. 2B). However, the pili-like appendages were not directly associated with the bacteria. Since the specimens were not subjected to chemical fixation before they were examined by electron microscope, we suspected that the pili could have been dislodged from the bacteria. In order to better visualize these surface appendages, we first fixed the bacteria in glutaraldehyde followed by negative staining. This procedure enabled us to visualize the pili radiating from the surface of the bacteria (Fig. 2D). The presence of pili became more apparent when these specimens were subjected to critical point drying and examined by cold field emission scanning electron microscope (Fig. 2F). The production of pili appears to be dependent on genistein, since USDA257 grown in its absence failed to produce these surface appendages (Fig. $2 \mathrm{C}$ and $\mathrm{E}$ ). We also evaluated the ability of several other flavonoids to promote the formation of pilus-like surface appendages. Daidzein, apigenin, and luteolin, compounds that have been previously shown to activate the nodABC genes of USDA257 (Krishnan and Pueppke 1991), stimulate production of the pili. Noninducers of nodABC genes of USDA257, including biochanin A and umbelliferone, were unable to elaborate pili. Soybean seed exudates from cultivars McCall and Peking also induced USDA257 to produce pili (data not shown).

We also isolated the surface appendages from USDA257 grown in YEM liquid cultures with inducers and examined them by transmission electron microscopy (Fig. 3). The isolated surface appendages from USDA257 grown in the presence of genistein consisted mostly of narrow filamentous appendages (pili) of about 6 to $8 \mathrm{~nm}$ in diameter (Fig. 3A). A few flagella were also seen, but their abundance was relatively low when compared with that of pili. The production of the pili appears to be dependent on TTSS, since rhcJ- and rhcC1-negative mutants failed to elaborate pili. However, these mutants retained the ability to produce flagella (Fig. 3B and C). Similarly, a nodD1-negative mutant of USDA257 was unable to elaborate pili upon flavonoid induction (Fig. 3D).

\section{Identification of proteins associated with USDA257 flagella and pili.}

Polyacrylamide gel analysis of isolated flagella of USDA257 revealed two abundant proteins of 34 and $36 \mathrm{kDa}$ (Fig. 4). These two abundant proteins appear to be flagellin subunits. This observation was confirmed by Western blot analysis using antibodies raised against the purified $S$. meliloti RMB7201 flagellin. The antibodies specifically cross-reacted against the 34- and 36-kDa polypeptides (data not shown). Isolated pili from genistein-induced USDA257 cells, when resolved by sodium dodecyl sulfate-polyacrylamide gel electrophoresis (SDS-PAGE), showed several abundant proteins, prominent among them were 64-, 38-, 25-, 18-, and 7-kDa proteins (Fig. 4). These proteins were absent in the flagella preparations, indicating that they are specifically associated with pili. In addition, these proteins were absent from $r h c N-$, $r h c C 1-$, and $r h c J$-negative mutants. The 34- and 36-kDa flagellin subunits were not readily detected in the pili preparations (Fig. 4). This may be due to the fact that the genistein-induced cultures of USDA257 contain a much greater abundance of pili relative to flagella. We further purified the pili by sucrose density centrifugation (Roine et al. 1997) and used this purified preparation to identify the proteins that are associated with it. Western blot analysis using antibodies raised against NopX, Nop38, and Nop7 gave positive reactions with all the three antibodies, confirming that these three proteins were associated with USDA257 pili (Fig. 5).

\section{TTSS play an important role in nodulation.}

We examined the symbiotic properties of USDA257 TTSS mutants by inoculating them on four legume hosts (Table 1). All the TTSS mutants that we examined formed a lower number of nodules on soybean cultivar Peking in comparison with the wild-type parent USDA257. Similar reduction in the nodulation was also observed with Macroptilium atropurpureum. However, the TTSS mutants were not affected in their ability to nodulate Vigna unguiculata and produced similar number of nodules as USDA257. The USDA257 ttsI mutant was unable to nodulate soybean cultivar McCall and behaved exactly like USDA257, producing only rudimentary swellings on soybean roots.

\section{DISCUSSION}

The complete nucleotide sequence of the TTSS has been reported previously for Rhizobium sp. strain NGR234 (Freiberg et al. 1997), M. loti (Kaneko et al. 2000), B. japonicum USDA110 (Göttfert et al. 2001), and $R$. etli CFN42 (NCBI database, accession number U80928). Although the sequence reported here is the first for a cultivar-specific symbiont, the genetic organization of the TTSS of USDA257 and NGR234 is



Fig. 4. Sodium dodecyl sulfate-polyacrylamide gel electrophoresis (SDSPAGE) analysis of the isolated surface appendages of Sinorhizobium fredii USDA257. Surface appendages from wild-type USDA257 (lane A), $r h c N$ (lane B), $r h c C 1$ (lane C), rhcJ (lane D), and ttsI (lane E) mutants grown in yeast extract-mannitol media containing genistein were suspended in SDS sample buffer and were resolved on a 15\% SDS-PAGE gel. The resolved proteins were visualized by staining the gel with Coomassie Brilliant Blue. The sizes of the molecular weight markers in $\mathrm{kDa}$ are also shown. 
98\% identical. In addition to the TTSS genes, the nucleotide sequences of several other nodulation genes of these two organisms also reveal remarkable similarity with each other (Relić et al. 1994). DNA subtraction-hybridization studies have shown that NGR234 and USDA257 share most of the genomic background and are closely related phylogenetically (Perret et al. 1994). These observations suggest a common ancestry for these two broad-host range symbionts. Interestingly, the TTSS of USDA257 and B. japonicum USDA110, two symbionts of soybean, shows only limited sequence homology, and their genetic organization is also quite different. In addition to the absence of NopX, a soybean-cultivar specificity protein, the TTSS of B. japonicum USDA110 contains several other ORFs with unknown functions (Göttfert et al. 2001).

USDA257 nodulates 72 genera of legumes and the nonlegume Parasponia andersonii (Pueppke and Broughton 1999). NGR234 has even broader host range than USDA257 and nodulates 112 genera (Pueppke and Broughton 1999). The exceptionally broad host range of NGR234 has been attributed to its ability to elaborate a diverse array of Nod factors (Price et al. 1992), but Nod factors alone cannot fully explain the basis for broad host range. For example, NGR234 produces the same set of Nod factors as does USDA257 but still cannot nodulate soybeans. This implies that, in addition to Nod factors, other signal molecules such as the extracellular proteins delivered by the TTSS may also play a crucial role in regulating nodulation. Our results show that proteins secreted via the TTSS control

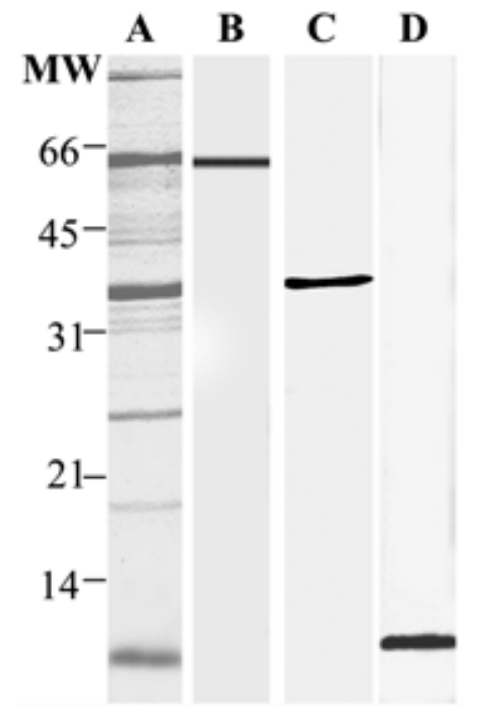

Fig. 5. Immunological identification of proteins associated with sucrosegradient purified surface appendages of Sinorhizobium fredii USDA257. Purified pili proteins from USDA257 were resolved by sodium dodecyl sulfate-polyacrylamide gel electrophoresis (lane A) and were electrophoretically transferred to a nitrocellulose membrane and probed with antibodies raised against the following proteins: lane B, NopX, lane C, Nop38, and lane D, Nop7. The sizes of the molecular weight markers in $\mathrm{kDa}$ are also shown (lane A). the nodulation on soybean cultivars McCall and Peking. Similarly NGR234 rhc mutants show altered nodulation phenotype on Pachyrhizus tuberosus and Tephrosia vogelii (Viprey et al. 1999). These observations are consistent with the suggestion that flavonoid-inducible TTSS proteins along with flavonoids and Nod factors are the three important symbiotic signals required for successful nodulation (Broughton et al. 2000).

We have demonstrated that USDA257 produces extracellular appendages (pili) when grown in the presence of nod geneinducing compounds. In plant and animal pathogenic bacteria, the TTSS is used to inject effector proteins into the plasma membrane and cytosol of the host cells (Galan and Collmer 1999). The delivery of the Salmonella typhimurium effector proteins into the host cells is believed to be mediated by a macromolecular complex (needle complex) that spans both the inner and outer bacterial membranes (Kubori et al. 1998). The needle complexes may serve as hollow conduits through which type III secreted proteins are transferred to the eukaryotic cells. In addition to the needle complexes, other supramolecular structures have also been reported. For example, E. coli and $S$. typhimurium produce filamentous appendages that are about 50 $\mathrm{nm}$ in diameter (Ginocchio et al. 1994; Knutton et al. 1998). In contrast, the plant pathogen Pseudomonas syringae produces Hrp pili that are much thinner (6 to $8 \mathrm{~nm}$ in diameter) (Roine et al. 1997) similar to those of USDA257.

The function of the type III secreted proteins of animal pathogens such as Shigella and Yersinia is to subvert the mammalian immune system (Cornelis and Wolf-Watz 1997). Yersinia spp. secrete several proteins (Yops) after direct contact with eukaryotic host cells. Some of these Yops are targeted into the eukaryotic cytosol, where they carry out distinct functions that ultimately lead to the death of the host cells. In plant pathogenic bacteria, the hrp genes, which encode the components of TTSS, are essential for elicitation of the hypersensitive response in resistant plants and of disease in susceptible plants (He 1998). Mutations in the $h r p$ genes eliminate the virulence of the bacteria. Plant pathogenic bacteria secrete two groups of proteins through the Hrp secretion system (He 1998). The first group of proteins (avirulence proteins) is directly targeted into the host cells. The second group of proteins, such as harpin, that elicit HR response when infiltrated into the intercellular space of plant leaves does not appear to be secreted into the host cell. In the case of symbiotic bacteria such as USDA257 and NGR234, the type III secreted proteins appear to play an important role in regulating nodulation on legume roots. Interestingly, the rhc mutants, which were unable to secrete Nops, had varying symbiotic phenotypes on their hosts. In the case of USDA257, the abolition of protein secretion results in drastic phenotypic effect on soybean nodulation. Unlike the wild-type USDA257, the $r h c$ mutants have acquired the ability to form nitrogen-fixing nodules on soybean cultivar McCall. However, the absence of the type III secreted proteins appears to have no effect on cowpea nodulation. Based on the current study and that of Viprey and associates (1998), it is apparent that the type III secreted proteins can either positively or negatively affect the nodulation process in a host-dependent manner.

Table 1. Symbiotic response of legume species to inoculation with Sinorhizobium fredii USDA257 and the type III secretion system mutants

\begin{tabular}{|c|c|c|c|c|}
\hline \multirow[b]{2}{*}{ Strain } & \multicolumn{4}{|c|}{ Number of nodules ${ }^{a}$} \\
\hline & Soybean cv. Peking & Soybean cv. McCall & Siratro & Cowpea \\
\hline USDA257 & $21 \pm 1.03$ & 0 & $13 \pm 0.98$ & $13 \pm 0.99$ \\
\hline Rhc C mutant & $8 \pm 1.5$ & $8 \pm 0.92$ & $5 \pm 0.51$ & $10 \pm 0.83$ \\
\hline RhcJ mutant & $8 \pm 0.75$ & $10 \pm 1.30$ & $4 \pm 0.46$ & $12 \pm 0.74$ \\
\hline RhcN mutant & $8 \pm 0.70$ & $6 \pm 0.64$ & $7 \pm 1.16$ & $11 \pm 1.18$ \\
\hline TtsI mutant & $12 \pm 1.24$ & 0 & $10 \pm 1.03$ & $9 \pm 1.51$ \\
\hline
\end{tabular}

${ }^{\mathrm{a}}$ Data represent mean number of nodules per plant $(n=16$ plants per treatment). Nodules were counted 25 days after inoculation. 
Biochemical analysis of the USDA257 pili preparations reveals the association of several Nops with the purified pili. The most prominent among them are Nop7, Nop38, and NopX. Even though Western blot analysis indicates that these proteins are localized on the pili, we cannot exclude the possibility that this association may have resulted due to an artifact of the purification procedure. Electron microscopy studies using intact bacteria may provide conclusive evidence for the association of Nop7, Nop38, and NopX with the pili. Our repeated attempts to localize the Nops on the intact bacterial cells have not been successful, due to technical problems. We also do not know if the type III secreted proteins of the symbiotic bacteria interact at the root surface or enter into the host cells. We are in the process of generating type III secreted proteins that have been tagged with green fluorescent protein (GFP). We intend to use the GFP-tagged proteins to monitor the delivery of such proteins into the host cells.

\section{MATERIALS AND METHODS}

\section{Microbiological techniques.}

Bacterial strains and plasmids are listed in Table 2. Rhizobium and $E$. coli strains were maintained as stock cultures in $25 \%$ glycerol at $-70^{\circ} \mathrm{C}$. Rhizobium strains were cultured in YEM broth (Vincent 1970 ) at $30^{\circ} \mathrm{C}$, and E. coli strains were grown in Luria-Bertani medium (Sambrook et al. 1989) at $37^{\circ} \mathrm{C}$. When appropriate, antibiotics were added at the following concentrations ( $\mu \mathrm{g}$ per $\mathrm{ml}$ ): ampicillin, 50; kanamycin, 50; tetracycline, 10; and spectinomycin, 50.

\section{Molecular methods.}

Plasmid isolation, restriction digestion, DNA ligation, Southern hybridization, and other procedures with nucleic acids followed the general protocols of Sambrook and associates (1989).

\section{Construction of tts $I$ and rheN mutants.}

A 2.4-kb PstI/EcoRI fragment from pGEm-7zf6RinodD2 was inserted into pBluescript II SK+ (Stratagene, La Jolla, CA, U.S.A.) to produce pBS24ttsI. This plasmid was digested with SacII, and the ends were converted to blunt ends by addition of Klenow fragment. A spectinomycin-resistant $2.0-\mathrm{kb} \Omega$ cassette was then cloned into blunt ends of the above plasmid to yield $\mathrm{pBS} 24 t t s I \Omega$. A 4.4-kb fragment was excised from $\mathrm{pBS} 24 t t s I \Omega$ by digestion with PstI and EcoRI and was treated with Klenow fragment. The insert was purified by agarose gel electrophoresis and was cloned into the SmaI site of pJQ200ucl (Quandt and Hynes 1993) to produce pJQ200uc124ttsI $\Omega$. This plasmid was introduced into USDA257 by triparental mating, with pRK2013 as a helper plasmid (Figurski and Helinski 1979). Marker exchange was forced by selection on minimal media

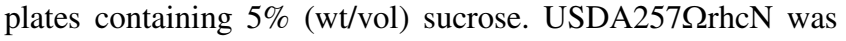
obtained using constructs originally made for generating the corresponding mutant in NGR234 (Viprey et al. 1998). USDA257 rhc $C 1$ and $r h c J$ mutants have been described earlier (Meinhardt et al. 1993).

\section{Isolation and purification \\ of USDA257 surface appendages.}

Bacterial surface-associated appendages were isolated from USDA257 cultures grown in $100 \mathrm{ml}$ of liquid YEM. Bacteria were removed from the culture medium by centrifugation at $11,300 \times g$ for $30 \mathrm{~min}$. The clear supernatant was subjected to ultracentrifugation in a Beckman SW 50.1 rotor at $150,000 \times g$ for $90 \mathrm{~min}$. The pellet was resuspended in a small volume of sterile water and was designated as isolated surface appendages. Aliquots of this fraction were used for transmission electron microscopy or gel electrophoresis.

Purification of the bacterial appendages from 100-ml cultures of USDA257 was carried out according to Roine and associates (1997). The surface appendages obtained as described above were resuspended in $10 \mathrm{mM}$ Tris- $\mathrm{HCl}(\mathrm{pH}$ 7.5) and were subjected to another round of ultracentrifugation in a 10:60 (wt/wt) percent sucrose gradient in a Beckman SW 50.1 rotor at $80,000 \times g$ for $20 \mathrm{~h}$. After centrifugation, the gradient was separated into 10 fractions and was analyzed by SDS-PAGE (Laemmli 1970). Transmission electron microscope examination revealed that fraction 10 contained the purified pili. This fraction was used for Western blot analysis.

\section{Electrophoresis and Western blot analysis.}

Proteins associated with surface appendages from USDA257 and $r h c$ mutants were resolved by SDS-PAGE with the discontinuous buffer system of Laemmli (1970). The slab gel $(10 \times 8$ $\times 0.75 \mathrm{~cm})$ consisted of separation and stacking gels of 15 and $4 \%$ acrylamide, respectively. Electrophoresis was performed at a 20 - $\mathrm{mA}$ constant current per gel until the tracking dye reached the bottom of the gel. The proteins were visualized by staining with Coomassie Brilliant Blue. Western blot analyses using sucrose-gradient purified surface appendages were performed, essentially as described by Burnett (1981). The production of antibodies to NopX, Nop38, and Nop7, which were previously referred to as SR1, SR3, and SR5, respectively, has been described earlier (Krishnan 2002; Krishnan et al. 1995). The antibodies were diluted 1:3000 in Tris-buffered saline (TBS; 10 $\mathrm{mM}$ Tris- $\mathrm{HCl}, \mathrm{pH} 7.5,500 \mathrm{mM} \mathrm{NaCl}$ ) containing 5\% (wt/vol) nonfat dried milk. Immunoreactive polypeptides were identified by following the horseradish peroxidase color development procedure provided by the manufacturer (Bio-Rad Laboratories, Inc., Richmond, CA, U.S.A.).

Table 2. Bacterial strains and plasmids used in this study

\begin{tabular}{|c|c|c|}
\hline Strain/Plasmid & Relevant characteristics & Source/Reference \\
\hline Escherichia coli $\mathrm{DH} 5 \alpha$ & $\phi 80$ lacZAM15 (lacZYA-argF), U169 hsdR17 recA1 endA1 thi-1 & Gibco BRL, Gaithersburg, MD, U.S.A. \\
\hline Sinorhizobium fredii USDA257 & Broad host range, Nod $^{+}$on soybean & Heron and Pueppke 1984 \\
\hline 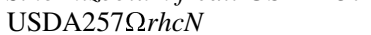 & USDA257 derivative Containing an $\Omega$ insertion in $r h c N, \mathrm{Sp}^{\mathrm{r}}$ & This study \\
\hline USDA257 $2 t t s I$ & USDA257 derivative Containing an $\Omega$ insertion in $t t s I, \mathrm{Sp}^{\mathrm{r}}$ & This study \\
\hline USDA257mm34 & USDA257 derivative Containing a miniMu insertion in $r h c J, \mathrm{Kn}^{\mathrm{r}}$ & Meinhardt et al. 1993 \\
\hline USDA257mm17 & USDA257 derivative Containing a miniMu insertion In $r h c C 1, \mathrm{Kn}^{\mathrm{r}}$ & Meinhardt et al. 1993 \\
\hline \multicolumn{3}{|c|}{ e } \\
\hline pGEM-7zf(+) & $\mathrm{Ap}^{\mathrm{r}}$ & Promega, Madison, WI, U.S.A. \\
\hline pBluescript II SK (+) & $\mathrm{Ap}^{\mathrm{r}}$ & Stratagene, La Jolla, CA, U.S.A. \\
\hline pGEM-T easy & $A p^{r}$ & Promega \\
\hline pJQ200uc1 & $\mathrm{Gm}^{\mathrm{r}}$ & Quandt and Hynes 1993 \\
\hline pHBK447 & $\mathrm{Tc}^{\mathrm{r}}$, pLAFR 1 cosmid carrying TTSS genes from USDA257 & This study \\
\hline pRK1489 & $\mathrm{Tc}^{\mathrm{r}}$, nodD 2 containing cosmid of USDA257 in pLAFR 1 & Krishnan and Pueppke 1991 \\
\hline pRFDH410 & $\mathrm{Ap}^{\mathrm{r}}, 8.0-\mathrm{kb}$ EcoRI fragment containing nolBTUVWX in $\mathrm{pTZ19u}$ & Meinhardt et al. 1993 \\
\hline
\end{tabular}




\section{Transmission electron microscopy.}

USDA257 cells grown in the presence or absence of $1-\mu \mathrm{M}$ genistein were spun down, washed three times in distilled water, resuspended in sterile water, and placed on carbon-coated copper grids. The bacteria on the grids were fixed in $2 \%$ gluteraldehyde and $2 \%$ paraformaldehyde for $15 \mathrm{~min}$ at room temperature. Fixed colonies were washed briefly in distilled water and stained with $1 \%$ phosphotungstic acid $(\mathrm{pH} 6.5)$. The grids then were examined with a JOEL JEM electron microscope at $100 \mathrm{kV}$. Pili and flagella were also observed with transmission electron microscope by pacing drops of isolated bacterial surface appendages on carbon-coated copper grids followed by staining with $1 \%$ phosphotungstic acid ( $\mathrm{pH} 6.5)$.

\section{Cold field emission scanning electron microscopy.}

USDA257 cells were placed on poly-L-lysine-coated (1 $\mathrm{mg} / \mathrm{ml}$ ) cover slips and allowed to settle for $15 \mathrm{~min}$. Colonies on the cover slips were fixed for $30 \mathrm{~min}$ at room temperature, using $2 \%$ gluteraldehyde and $2 \%$ paraformaldehyde in $0.1 \mathrm{M}$ cacodylate buffer. Fixed colonies were washed briefly in distilled water and then postfixed for 30 min with $1 \%$ osmium tetroxide. The specimens were dehydrated in a graded series of ethanol, subjected to critical point drying, and sputter-coated with lead. The specimens were examined with a S-4700 cold field emission scanning electron microscope (Hitachi, Japan) at $5.0 \mathrm{kV}$ and $10 \mu \mathrm{A}$.

\section{Plant assays.}

Legume seeds were surface-sterilized and were germinated at $28^{\circ} \mathrm{C}$ on water-agar plates for three days. Seedlings were dipped in a suspension of inoculating bacteria of a known concentration and were planted directly into aseptically prepared plastic growth pouches premoistened with nitrogen-free nutrient solution. Plants were placed in a growth chamber that was set at a constant temperature of $28^{\circ} \mathrm{C}$ with light intensity of $500 \mu \mathrm{E} \mathrm{m}^{-2} \mathrm{~s}^{-1}$ under a 12-h day and night cycle. Plants were harvested 25 days after inoculation, and nodulation responses were assessed visually.

\section{ACKNOWLEDGMENTS}

We thank L. L. Darrah for critical reading of this manuscript. This research was supported by a competitive research grant from the U.S. Department of Agriculture.

\section{LITERATURE CITED}

Anderson, D. M., and Schneewind, O. 1997. A mRNA signal for the type III secretion of Yop proteins by Yersinia enterocolitica. Science 278:1140-1143.

Brown, I. R., Mansfield, J. W., Taira, S., Roine, E., and Romantschuk, M. 2001. Immunocytochemical localization of HrpA and HrpZ supports a role for the Hrp pilus in the transfer of effector proteins from Pseudomonas syringae pv. tomato across the host cell wall. Mol. PlantMicrobe Interact. 14:394-404.

Baker, B., Zambryski, P., Staskawicz, B., and Dinesh-Kumar, S. P. 1997. Signaling in plant-microbe interactions. Science 276:726-733.

Broughton, W. J., Jabbouri, S., and Perret, X. 2000. Keys to symbiotic harmony. J. Bacteriol. 182:5641-5672.

Burnett, W. N. 1981. Western blotting: Electrophoretic transfer of proteins from SDS-polyacrylamide gels to unmodified nitrocellulose and radiographic detection with antibody and radioiodinated protein-A. Anal. Biochem. 112:195-203.

Casper-Lindley, C., Dahlbeck, D., Clark, E. T., and Staskawicz, B. J. 2002. Direct biochemical evidence for type III secretion-dependent translocation of the AvrBs2 effector protein into plant cells. Proc. Natl. Acad. Sci. U.S.A. 99:8336-8341.

Cornelis, G. R., and Wolf-Watz, H. 1997. The Yersinia Yop virulon: A bacterial system for subverting eukaryotic cells. Mol. Microbiol. 87:861-867.

Freiberg, C., Fellay, R., Bairoch, A., Broughton, W. J., Rosenthal, A., and
Perret, X. 1997. Molecular basis of symbiosis between Rhizobium and legumes. Nature 387:394-401.

Figurski, D., and Helinski, D. R. 1979. Replication of an origin-containing derivative of plasmid $\mathrm{RK}_{2}$ dependent on a plasmid function provided in trans. Proc. Natl. Acad. Sci. U.S.A. 76:1648-1652.

Galan, J. E., and Collmer, A. 1999. Type III secretion machines: Bacterial devices for protein delivery into host cells. Science 284:1322-1328.

Ginocchio, C., Olmsted, S. B., Wells, C. L., and Galan, J. E. 1994. Contact with epithelial cells induces the formation of surface appendages on Salmonella typhimurium. Cell 76:717-724.

Göttfert, M., Rothlisberger, S., Kundig, C., Beck, C., Marty, R., and Hennecke, H. 2001. Potential symbiosis-specific genes uncovered by sequencing a 410-kilobase DNA region of the Bradyrhizobium japonicum chromosome. J. Bacteriol. 183:1405-1412.

He, S. Y. 1998. Type III protein secretion systems in plant and animal pathogenic bacteria. Annu. Rev. Phytopathol. 36:363-392.

Heron, D. S., and Pueppke, S. G. 1984. Mode of infection, nodulation specificity, and indigenous plasmids of 11 fast-growing Rhizobium japonicum strains. J. Bacteriol. 160:1061-1066.

Jin, Q., and He, S.-Y. 2001. Role of the Hrp pilus in type III protein secretion in Pseudomonas syringae. Science 294:2556-2558.

Kaneko, T., Nakamura, Y., Sato, S., Asamizu, E., Kato, T., Sasamoto, S., Watanabe, A., Idesawa, K., Ishikawa, A., Kawashima, K., Kimura, T., Kishida, Y., Kiyokawa, C., Kohara, M., Matsumoto, M., Matsuno, A., Mochizuki, Y., Nakayama, S., Nakazaki, N., Shimpo, S., Sugimoto, M., Takeuchi, C., Yamada, M., and Tabata, S. 2000. Complete genome structure of the nitrogen-fixing symbiotic bacterium Mesorhizobium loti. DNA Res. 7:331-338.

Knutton, S., Rosenshine, I., Pallen, M. J., Nisan, I., Neves, B. C., Bain, C., Wolff, C., Dougan, G., and Frankel, G. 1998. A novel EspA-associated surface organelle of enteropathogenic Escherichia coli involved in protein translocation into epithelial cells. EMBO (Eur. Mol. Biol. Organ.) J. 17:2166-2176.

Krishnan, H. B. 2002. NolX of Sinorhizobium fredii USDA257, a type III-secreted protein involved in host range determination, is localized in the infection threads of cowpea (Vigna unguiculata [L.] Walp) and soybean (Glycine max [L.] Merr.) nodules. J. Bacteriol. 184:831-839.

Krishnan, H. B., and Pueppke, S. G. 1991. Sequence and analysis of the nodABC region of Rhizobium fredii USDA257, a nitrogen-fixing symbiont of soybean and other legumes. Mol. Plant-Microbe Interact. 4:512-520.

Krishnan, H. B., and Pueppke, S. G. 1993. Flavonoid inducers of nodulation genes stimulate Rhizobium fredii USDA257 to export proteins into the environment. Mol. Plant-Microbe Interact. 6:107-113.

Krishnan, H. B., Kuo, C.-I., and Pueppke, S. G. 1995. Elaboration of flavonoid-induced proteins by the nitrogen-fixing soybean symbiont Rhizobium fredii is regulated by both nodD1 and nodD2, and is dependent on the cultivar-specificity locus, nolXWBTUV. Microbiology 141:2245-2251.

Krupski, G., Gotz, R., Ober, K., Pleier, E., and Schmitt, R. 1985. Structure of complex flagellar filaments in Rhizobium meliloti. J. Bacteriol. 162:361-366.

Kubori, T., Yamaguchi, S., Nakamura, D., Uralil, J., Lara-Tejero, M., Sukhan, A., Galan, J. E., and Aizawa, S. I. 1998. Supramolecular structure of the Salmonella typhimurium type III protein secretion system. Science 280:602-605.

Lloyd, S. A., Sjostrom, M., Andersson, S., and Wolf-Watz, H. 2002. Molecular characterization of type III secretion signals via analysis of synthetic N-terminal amino acid sequences. Mol. Microbiol. 43:51-59.

Laemmli, U. K. 1970. Cleavage of structural proteins during the assembly of the head of bacteriophage T4. Nature 227:680-685.

Lee, C. A. 1997. Type III secretion systems: Machines to deliver bacterial proteins into eukaryotic cells? Trends Microbiol. 5:149-156.

Leigh, J. A., Signer, E. R., and Walker, G. C. 1985. Exopolysaccharidedeficient mutants of Rhizobium meliloti that form ineffective nodules. Proc. Natl. Acad. Sci. U.S.A. 85:6231-6235.

Marie, C., Broughton, W. J., and Deakin, W. J. 2001. Rhizobium type III secretion systems: Legume charmers or alarmers? Curr. Opin. Plant Biol. 4:336-342.

Meinhardt, L. W., Krishnan, H. B., Balatti, P. A., and Pueppke, S. G. 1993. Molecular cloning and characterization of a sym plasmid locus that regulates cultivar-specific nodulation of soybean by Rhizobium fredii USDA257. Mol. Microbiol. 9:17-29.

Perret, X., Fellay, R., Bjourson, A. J., Cooper, J. E., Brenner, S., and Broughton, W. J. 1994. Subtraction hybridization and shot-gun sequencing: A novel approach to identify symbiotic loci. Nucleic Acids Res. 22:1335-1341.

Pettersson, J., Nordfelth, R., Dubinina, E., Bergman, T., and Gustafson, M. 1996. Modulation of virulence factor expression by pathogen target cell contact. Science 273:1231-1233. 
Price, N. P. J., Relić, B., Talmont, F., Lewin, A., Promé, D., Pueppke, S. G., Maillet, F., Dénarié, J., Prome, J.-C., and Broughton, W. J. 1992. Broad-host-range Rhizobium species NGR234 secretes a family of carbamoylated, and fucosylated, nodulation signals that are $O$-acetylated or sulphated. Mol. Microbiol. 6:3575-3584.

Pueppke, S. G., and Broughton, W. J. 1999. Rhizobium sp. strain NGR234 and $R$. fredii USDA257 share exceptionally broad, nested host ranges. Mol. Plant-Microbe Interact. 12:293-318.

Quandt, U., and Hynes, M. F. 1993. Versatile suicide vectors which allow direct selection for gene replacement in gram-negative bacteria. Gene 127:15-21.

Relić, B., Perret, X., Estrada-Garcia, M. T., Kopcinska, J., Golinowski, W., Krishnan, H. B., Pueppke, S. G., and Broughton, W. J. 1994. Nod factors of Rhizobium are a key to the legume door. Mol. Microbiol. 13:171-178

Roine, E., Wei, W., Yuan, J., Nurmiaho-Lassila, N., Kalkkinen, N., Romantschuk, M., and He, S. Y. 1997. Hrp pilus: An hrp-dependent bacterial surface appendage produced by Pseudomonas syringae pv. tomato DC3000. Proc. Natl. Acad. Sci. U.S.A. 94:3459-3464.

Sambrook, J., Fritsch, E. F., and Maniatis, T. 1989. Molecular Cloning: A Laboratory Manual, 2nd ed. Cold Spring Harbor Laboratory Press, Cold Spring Harbor, NY, U.S.A.

Sutton, J. M., Lea, E. J., and Downie, J. A. 1994. The nodulation-signaling protein NodO from Rhizobium leguminosarum biovar viciae forms ion channels in membranes. Proc. Natl. Acad. Sci. U.S.A. 91:9990-9994.

Van Gijsegem, F., Vasse, J., Camus, J. C., Marenda, M., and Boucher, C. 2000. Ralstonia solanacearum produces hrp-dependent pili that are required for PopA secretion but not for attachment of bacteria to plant cells. Mol. Microbiol. 36:249-260.

Vincent, J. M. 1970. A Manual for the Practical Study of Root-Nodule Bacteria. Blackwell Scientific, Oxford, U.K.

Viprey, V., Greco, A. D., Golinowski, W., Broughton, W. J., and Perret, X. 1998. Symbiotic implications of type III protein secretion machinery in Rhizobium. Mol. Microbiol. 28:1381-1389. 